\title{
Anggaran Pendidikan Pasca Amandemen UUD 1945
}

\author{
Edy Suandi Hamid
}

The fundamental problem that emerges the controversy relating to amendment the article 31 verse 4 regarding the budget of education. The article 31 verse 4 contains that the budget of national education either taken from national state budget or province budget at least $20 \%$. After conducting amendment and it is not implement raises many questions and many interpretations on $20 \%$. To solve the problem it is better to formulate rigid interpretation. This important to do because of either the implementation as soon as possible or the target that will be conducted step in step.

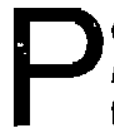

erhatian para pendiri negara (found ing fathers) Republik Indonesia terhadap pembangunan bidang pendidikan sangat besar. Ini tercermin dari pemikiran-pemikiran yang tersurat dalam Pembukaan UUD 1945 maupun dalam pasal dan ayat-ayat pada UUD tersebut. Pada Pembukaan UUD 1945, perhatian ini tercermin dari pernyataan yang antara lain menyatakan bahwa pemerintahan negara indonesia dibentuk untuk "mencerdaskan kehidupan bangsa". Untuk mendukung tujuan tersebut, dalam Pasal 31 disuratkan bahwa (1) Tiap-tiap warga negara berhak mendapat pengajaran dan (2) Pemerintah mengusahakan dan menyelenggarakan satu sistem pengajaran nasional, yang diatur dengan undang-undang.

Apa yang termuat dalam Pembukaan dan batang tubuh UUD 1945 tersebut menunjukkan bahwa para pendiri negara bukan saja sadar akan keterbelakangan manusia Indonesia waktu itu, melainkan juga berpikiran maju dan melihat ke depan bahwa aspek pembangunan pendidikan harus dijadikan prioritas. Para pendiri negara agaknya beranggapan bahwa pembangu-nan manusia melalui pendidikan merupakan pi- lar untuk terjadinya pembangunan bidangbidang lainnya. Masyarakat yang tidak terdidik akan sulit melepaskan dirinya dari keterbelakangan dan kemiskinan. Kenyataannya, situasi yang demikianlah yang terjadi dengan masyarakat Indonesia pada masa penjajahan dan awal kemerdekaan tersebut.

Asumsi yang demikian, baik dilihat dari secara empirik maupun teoritik, memang betul. Jika dilihat fakta empirik di negaranegara yang terbelakang, umumnya tingkat pendidikannya rendah. Misalnya dengan melihat data Indeks Pembangunan Manusia (IPM), yang di dalamnya memasukkan unsur variabel pendidikan dan secara rutin setiap tahun dipublikasikan oleh UNDP (United Nations Development Program), menunjukkan negara-negara yang terbelakang memiliki IPM yang rendah. Negara-negara seperti Nigeria, Ethiopia, Mozambik di Afrika, atau Bangladesh, Laos, dan Nepal di Asia merupakan contoh negara-negara yang IPM-nya rendah dan masuk dalam kategori negara-negara terbelakanng (less developed countries).

Pengaruh langsung pembangunan manusia terhadap pertumbuhan ekonomi 
dapat dilihat pada penelitian yang dilakukan oleh Bank Dunia (1993) dan Bank Pembangunan Asia (ADB, 1997). Ditemukan bahwa tingkat melek huruf yang tinggi, tingkat kematian bayi yang rendah, dan tingkat kesenjangan dan kemiskinan yang rendah telah memberikan kontribusi positif terhadap pertumbuhan ekonomi yang sangat cepat di Asia Timur dan di Asia Tenggara (Kuncoro, 2002: 53). Kajian Lucas (1988) dan juga Easterly dan Levine (2001: 177220) menunjukkan variabel pendidikan, yang dilihat dari rata-rata lamanya sekolah, secara langsung mempengaruhi pertumbuhan ekonomi. Di negara maju, investasi pada sumber daya manusia juga merupakan sumber utama pertumbuhan ekonomi (Meier, 1995: 313).

Temuan-temuan ini menegaskan pentingnya pembangunan sektor pendidikan dalam upaya pembangunan nasional suatu negara secara keseluruhan. Secara deduktif dapat dijelaskan bahwa berhasilnya pembangunan manusia akan meningkatkan kualitas tenaga kerja dan masyarakat. Peningkatan kualitas tenaga kerja akan mendorong peningkatan produktivitasnya melalui berbagai aktivitas ekonomi, sehingga ekonomi daerah bisa berkembang dan kemampuan masyarakat membayar pajak dan retribusi meningkat. Dengan kata lain, investasi pada pembangunan manusia (human capital investment) akan meningkatkan produktivitas individual dan sosial (Ehrenberg dan Smith, 1996:325; Kaufman, 1986: 303-304). Hal ini pula yang menjadi pertimbangan dalam studi ini untuk menyusun formula transfer di Indonesia dengan memasukkan juga variabel pembangunan manusia tersebut.

\section{Hasil yang Dicapai}

Walaupun para pendiri Negara sudah menegaskan pentingnya pembangunan pendidikan tersebut, namun hasil yang diperoleh masih belum menggembirakan. Jika dilbandingkan dengan kondisi masa lalu, perkembangan sektor pendidikan Indonesia sudah menunjukkan kemajuan yang berarti. Namun demikian, jika dibandingkan dengan Negara-negara lain di sekitar kita, posisi Indonesia masih tertinggal.

Kemajuan sektor pendidikan ini bisa dilihat misalnya dari perkembangan penduduk yang tidak bisa baca-tulis atau tingkat buta huruf (illiteracy rate). Persentase penduduk berusia 15 tahun atau lebih yang tidak bisa baca-tulis ini menurun secara tajam dari $61 \%$ tahun 1960 menjadi hanya $11,6 \%$ tahun 1999 . Demikian juga dilihat dari rata-rata lamanya mengenyam pendidikan formal (mean years schooling) bagi penduduk usia 15 tahun atau lebih yang sudah menyelesaikan sekolahnya dalam satu dasawarsa terakhir ini, yakni dari tahun 1990 sampai 1999 sudah meningkat dari 5,3 tahun menjadi 6,7 tahun. Kemajuan yang sama juga terjadi tingkat melek huruf (iiteracy rate) yang semakin tinggi, tingkat drop-out sekolah yang semakin rendah, ataupun tingkat partsipasi sekolah (school participation rate) yang semakin tinggi.

Namun demikian kemajuan tersebutmasih relatif lamban jika dibandingkan dengan negara lain baik pada tingkat Asia maupun dunia. Jika dilihat Indeks Pembangunan Manusia (IPM) yang dua di antara empat variabelnya berkaitan dengan pendidikan, yaitu rata-rata lamanya sekolah dan tingkat melek huruf, posisi Indonesia berada pada peringkat yang relatif rendah. Laporan Pembangunan Manusia dari United Nations Development Programme (UNDP)'

${ }^{1}$ Variabel yang digunakan oleh UNDP dalam penetapan Indeks Pembangunan Manusia adalah usia harapan hidup (life of expectancy), tingkat melek huruf (literacy rate), lama sekolah (years 
menyimpulkan Indeks Pembangu-nan Manusia (Human Development index) Indonesia tahun 1999 berada pada peringkat 105 dari 174 negara yang disurvei, kemudian merosot menjadi peringkat 110 dari 173 negara pada tahun 2002. Angka ini menurun lagi menjadi peringkat 112 dari 175 negara tahun 2003. Bahkan di tingkat negara-negara ASEAN-6, Indonesia menempati peringkat terendah. Indeks Pembangunan Manusia ini lebih bersifat lebih menyeluruh dibandingkan indikator lainnya, seperti PQL/ (Physical Quality Life of Index) ataupun pendapatan per kapita (Meier dan Rauch, 2000: 7).

Rendahnya IPM ini tidak bisa dilepaskan dari rendahnya alokasi anggaran untuk bidang pendidikan tersebut, di samping juga bidang kesehatan. Pengeluaran pemerintah bidang pendidikan porsinya masih sangat kecil. Menurut Rektor UGM Sofian Effendi tahun 2002 alokasi anggaran pemerintah untuk pendidikan hanya $3,8 \%$ dari APBN atau sekitar $0,8 \%$ dari PDB (www.bisik. com $)^{2}$. Alokasi anggaran ini sangat kecil bukan saja dibandingkan dengan negara-negara maju, melainkan juga dibandingkan negara-negara sedang berkembang. Rata-rata anggaran pendidikan di negara maju adalah $5,1 \%$ dari GNP, sedang negara-negara berkembang berkisar $3,8 \%$ dari GNP. Sebagai gambaran anggaran pendidikan beberapa negara ASEAN seperti Malaysia, Singapura, dan Thailand masing-masing mengalokasikan $5,2 \% ; 3,0 \%$; dan $4,1 \%$ dari GNP-nya (muwnuansapersada.net).

Rendahnya anggaran pendidikan ini sudah merupakan masalah klasik di tanah air. Pada awal pemerintahan Orde Baru sudah ada upaya untuk mempercepat proses kemajuan pendidikan ini dengan dukungan dana anggaran pembangunan melalui proyek Inpres Sekolah Dasar. Inpres Sekolah Dasar ini secara substansial telah mampu memberikan peluang lebih luas bagi masyarakat untuk mengenyam pendidikan dasar, dan hasilnya antara lain bisa dilihat dari semakin tingginya tingkat melek huruf. Namun demikian anggaran pendidikan ini tetap masih terbatas, dan belum mampu memenuhi kebutuhan yang diharapkan. Misalnya saja untuk kesejahteraan para tenaga pengajarnya, masih jauh dai memadai. Hal ini berakibat pada banyaknya tenaga pengajar yang harus mengalokasikan waktunya untuk menambah pendapatan di luar tugas pokoknya. Dengan banyaknya tenaga pengajar yang bekerja "paruh waktu" tersebut, maka tidak mengherankan kalau kualitas output pendidikan menjadi rendah. Oleh karena itu sangat wajar jika kemudian muncul tuntutan agar pemerintah mengalokasikan dana lebih besar untuk bidang pendidikan tersebut.

\section{Amandemen Pasal Pendidikan}

Tuntutan untuk lebih memberikan prioritas pada pendidikan ini ternyata tidak hanya dalam kebijakannya, melainkan sampai landasan konstitusinya, yakni melalui proses amandemen pada UUD 1945. Dalam amandemen keempat UUD 1945 tahun 2002, bukan saja berkaitan dengan anggaran yang dimasukkan, melainkan jauh lebih luas dari itu. Secara tersurat dalam amandemen ini dikemukakan tentang kewajiban mengenyam pendidikan dasar, bentuk sistem pendidikan nasional, pengembangan iptek, dan sebagainya.

of shooling), dan pendapatan per kapita yang disesuaikan dengan paritas daya beli (purchasing power parity). Lihat Todaro, 2000: 72).

2 Data UNSFIR menunjukkan tahun 1997 anggaran pendidikan Indonesia mencapai $1,7 \%$ dari GNP. 
Amandemen pasal pendidikan dalam UUD 1945 telah mengubah Pasal 31 dari sebelumnya hanya dua ayat menjadi 5 ayat. Untuk Pasal 31 ayat 1 sama sekali tidak mengalami perubahan, yaitu "Setiap warga negara berhak mendapat pendidikan". Pada ayat selanjutnya berbunyi: (ayat 2) Setiap warga negara wajib mengikuti pendidikan dasar dan pemerintah wajib membiayainya; (3) Pemerintah mengusahakan dan menyelenggarakan satu sistem pendidikan nasonal, yang meningkatkan keimanan dan ketakwaan serta ahlak mulia dalam rangka mencerdaskan kehidupan bangsa, yang diatur dengan undang-undang; (4) Negara memprioritaskan anggaran pendidikan sekurang-kurangnya dua puluh persen dari anggaran pendapatan dan belanja negara serta dari anggaran pendapatan dan belanja daerah untuk memenuhi kebutuhan penyelenggaran pendidikan nasonal; dan (5) Pemerintah memajukan ilmu pengetahuan dan teknologi dengan menjunjung tinggi nilai-nilai agama dan persatuan bangsa untuk kemajuan peradaban serta kesejahteraan manusia.

Amandemen tersebut cukup luas, dan jika bisa dilaksanakan secara penuh dapat dipastikan akan berpengaruh secara signifikan bagi kemajuan pendidikan nasional. Namun dalam tataran pelaksanaan hal ini tidak semudah melakukan amandemen tersebut. Bahkan tafsir terhadap pasal tersebut masih belum seragam, sehingga berpengaruh pada pelaksanaan maupun penilaiannya. Sebagai contoh, hak untuk memperoleh pendidikan sejak sebelum amandemen sudah tersurat dalam UUD 1945, namun kenyataannya hak tersebut belum bisa diterima atau dinikmati oleh seluruh warga negara. Sebagian warga negara yang tidak mampu harus rela tidak mengenyam pendidikan formal sama sekali, atau hanya sebatas pendidikan dasar.
Akibatnya, masih banyak anak-anak usia sekolah yang tidak mengenyam bangku pendidikan formal.

Dengan amandemen ini maka menjadi wajib bagi setiap warga negara untuk mengikuti pendidikan dasar. Artinya, pemerintah harus memaksa mereka yang usia sekolah namun tidak bersekolah. Hal ini bukan persoalan mudah untuk melaksanakannya. Karena dalam kenyataannya, mereka yang ingin sekolah pun belum tentu bisa bersekolah karena tidak mampu membayar uang sekolah dan membeli perlengkapan sekolah. Walaupun selalu dikemukakan bahwa tidak ada biaya untuk pendidikan dasar di sekolah negeri, dalam kenyataannya anak-anak didik selalu saja dikenai berbagai biaya dengan dalih sebagai sumbangan. Di samping itu, dengan masih banyaknya penduduk Indonesia yang masih hidup di bawah garis kemiskinan, akan tidak mudah memaksa seseorang untuk bersekolah. Kendati biaya nantinya benarbenar bisa dihapusakan, masih ada persoalan berkaitan dengan pembelian perlengkapan sekolah seperti seragam, buku, dan lainlainnya. Oleh karena itu, jika melihat kondisi yang ada saat ini maka diperkirakan masih panjang waktu untuk bisa merealisasikan pasal-pasal pendidikan tersebut.

\section{Anggaran Pendidikan}

Satu hal yang masih dan banyak menimbulkan kontroversi adalah berkaitan dengan Pasal 31 ayat 4 berkaitan dengan anggaran pendidikan, yang menyuratkan bahwa sekurang-kurangnya dua puluh persen dari APBN dan APBD untuk memenuhi kebutuhan penyelenggaraan pendidikan nasional. Setelah amandemen dilakukan dan belum dalam tahapan implementasi, ayat ini sudah menimbulkan berbagai pertanyaan dan memunculkan berbagai tafsir atas angka "dua puluh persen" 
tersebut. Sampai saat ini tafsir yang baku mengenai angka tersebut masih belum jelas, baik dari sisi penerimaan maupun pengeluaran, dan apakah inj merupakan target atau keharusan untuk segera dilaksanakan.

Dari sisi penerimaan negara, angka $20 \%$ tersebut bisa diartikan bermacammacam. Misalnya, apakah angka tersebut diambil dari total penerimaan, atau hanya dari penerimaan dalam negeri saja. Apapun yang dipilih, dari sisi penerimaan ini saja akan menimbulkan perbedaan angka dan konsekuensi yang sangat besar. Dalam kenyataannya, dari sisi penerimaan ini memang tidak terlalu banyak dipertanyakan. Fokus polemik adalah dalam melihat alokasi pengeluarannya.

Dari sisi pengeluarannya tafsir-tafsir tersebut antara lain dilihat dari alokasi minimal $20 \%$ dari (1) pengeluaran rutin, pengeluaran pembangunan atau pengeluaran total. Dari sisi ini saja sudah menghasilkan tiga angka yang tidak sama dengan perbedaan yang sanga besar. Jika yang dimaksudkan adalah total pengeluaran (rutin dan pembangunan), maka untuk RAPBN 2003 saja - jika hanya melihat belanja pemerintah Pusat - dana yang harus dialokasikan mencapai Rp 24,1 triliun. Padahal jika yang dijadikan patokan adalah pengeluaran pembangunan, maka alokasi dana bidang pendidikan tersebut hanya $R p$ 5,45 triliun. Sebaliknya jika yang diajdikan ukuran adalah pengeluaran rutin maka lokasinya sebesar Rp 18,7 triliun; (2) dana yang dialokasikan ke departemen yang menangani masalah pendidikan (Depdiknas) saja. Jadi dalam hal ini pemerintah (pusat dan daerah) harus mengalokasikan $20 \%$ anggarannya ke Depdiknas, dan ini akan digunakan untuk membiayai kegiatan sektoral di bidang pendidikan tersebut. Dalam hal ini dana rutin untuk membayar gaji guru yang masuk dalam pengeluaran rutin tidak masuk dalam angka tersebut; (3) dana yang dialokasikan semua departemen yang terkait dengan peningkatan kualitas pendidikan. Dalam konteks ini pengeluaranpengeluaran departemen yang digunakan untuk diklat ataupun berbagai bentuk program untuk mendidik karyawannya sudah dapat dikategorikan anggaran pendidikan; dan (4) dana untuk bidang pendidikan yang dialokasikan ke departemen pendidikan dan dana rutin yang dibayarkan untuk membayar gaji-gaji tenaga yang bekerja di bidang pendidikan tersebut.

Ini baru sebagian tafsir dari apa yang dimaksud dengan alokasi dana pendidikan tersebut. Dengan tafsir yang berbeda, maka sulit untuk menilai dan mencari ukuran apakah perintah dalam UUD tersebut sudah dilaksanakan atau belum. Misalnya, jika berdasakan angka RAPBN 2003 tersebut dan dengan menggunakan ukuran anggaran pembangunan, maka alokasi dana pendidikan tersebut sudah terlampaui, yakni sudah $25 \%$ dari anggaran pembangunan. $\mathrm{Hal}$ ini dilihat dari rencana anggaran untuk Sektor 11 (pendidikan, kebudayaan, nasional, pemuda dan olah raga) yang jumlahnya $R p$ 13,64 triliun. Namun jika dilihat dari total anggaran, maka ảnggaran pendikan tersebut baru 5,8\% (Kompas, 29/8/2002). Padahal di luar Sektor 11 tersebut pemerintah masih mengalokasikan untuk bidang yang terkait dengan pendidikan aparatur berupa diklat kedinasan, balai latihan kerja dan sebagainya. Ilustrasi sederhana ini menunjukkan bahwa Pasal 31 (4) ini bisa menjadi "pasal karet" yang bisa ditafsirkan sesuai kebutuhan masing-masing orang. Pemerintah yang berkuasa bisa saja menafsirkan sesuai dengan kemampuannya untuk mengalokasikan dana ke sektor pendidikan ini. Jika pemerintah mempunyai perhatian yang tinggi pada bidang pendidikan, maka alokasinya akan besar. Sebaliknya jika 
kurang peka terhadap pembanguna pendidikan, alokas dana akan kecil.

Melihat kondisi yang demikian maka seharusnya ada tafsir baku untuk ayat tersebut yang secara hukum bisa dijadikan pegangan oleh semua pihak. Dengan demikian, seluruh elemen pemerintahan, baik di Pusat maupun daerah, akan mempunyai pegangan dan wajib melaksanakannya. Dalam hal ini mungkin Mahkamah Agung yang mempunyai otoritas untuk memberikan tafsir yang bisa menjadi pegangan tersebut. Namun karena ini masalahnya cukup kompleks, sebelum sampai kepada fatwa atau tafsir baku tersebut, ada baiknya Mahkamah Agung membentuk suatu tim yang bisa memberikan masukan-masukan mengenai tafsir tersebut. Hal ini bukan saja berkaitan dengan angka tersebut $20 \%$ dari pos anggaran yang mana, melainkan juga apakah jumlah tersebut harus segera dilaksanakan atau merupakan target yang secara bertahap harus diusahakan oleh pemerintah.

\section{Daftar Pustaka}

Badan Pusat Statistik, BAPPENAS, dan UNDP, 2001, Indonesia Human Development Report 2001 - Towards a New Consensus:- Democracy and human development in Indonesia, Jakarta:BPS, BAPPENAS, dan UNDP

Easterly, William, dan Ross Levine, 2001, "It is Not Factor Accumulation: Stylized Facts and Growth Model", dalam The World Bank Economic Review, Volume 15, No. 2, Cary, NC, Oxford: University Press.

Ehrenberg , Ronald G, dan Robert S Smith,
1996, Modern Labor Economics: Theory and Public Policy, Massachusetts: Addison-Wesley.

Habibi, Nadir et.al 2001, "Decentralization in Argentina", Economic Growth Center Discussion Paper Series, Paper No. 525, New Heaven: Economic Growth Center Yale University.

Kaufman, Bruce W, 1986, The Economics of Labor Markets and LaborReltions, Chicago: Dryden Press.

Kuncoro, Mudrajad, 2002, "Pengelolaan Fundamental Ekonomi Daerah", Bahan Belajar Legislative Course, Jakarta: Badan Pendidikan dan Pelatihan Departemen Dalam Negeri dengan Japan International Cooperation Agency.

Meier, Gerald M, 1995, Leading Issues in Economic Development, edisi keenam, New York, Oxford: University Press.

Meier, Gerald M, dan James E Rauch, 2000, Leading Issues in Economic Development, edisi ketujuh, New York: Oxford University Press.

Todaro, Michael, 2000, Economic Development. Edisi ketujuh, England: Addison-Wesley.

UNSFIR (United Nations Support Facility for Indonesian Recovery), 2000, Indonesia: The National Human Development Report 2000, Jakarta: UNSFIR.

www.bisik.com

www.nuansapersada.net 